\title{
Business analysis of black soldier fly (BSF) as an alternative feed for fish cultivation in Bogor City, West Java
}

\author{
M. Harja Supena ${ }^{1, *}$, Asnawi $^{1}$, Sobariah ${ }^{1}$, Suratman $^{1}$, Ganjar Wiryati $^{1}$, A. Subagio $^{1}$ \\ ${ }^{1}$ Fisheries Extension Study Program, The Jakarta Technical University of Fisheries, Indonesia
}

\begin{abstract}
The research was conducted at six Reduce Reuse Recycle (TPS 3R) waste disposal sites located in six sub-districts in Bogor City. At this waste disposal site, the amount of waste was enormous. That is why Bogor City Government seeks to overcome this problem by cultivating black soldier fly (maggot) as a substitution for cultivated fish feed. The purpose of this study was to determine the income and feasibility of maggot cultivation in Bogor City through several business analysis indicators, namely "Income per cycle," Revenue Cost Ratio (R/C), and Break-Even Point (BEP). The research was conducted from July to September 2020. The types of data collected are primary and secondary data. Data were collected based on interviews and direct observation with six maggot cultivators who stayed in six polling stations as catfish cultivators. Data processing and analysis were carried out using quantitative and qualitative descriptive methods. The result showed that income per cycle ( 2 weeks) was Rp. 41,495,000,-, R/C ratio was $1.077(1.1), \mathrm{BEP}_{(\mathrm{Rp})}$ was Rp. 38,223,654,-, and $\mathrm{BEP}_{\text {(unit) }}$ was $8,112 \mathrm{~kg}$. It can be concluded that the maggot cultivation business is feasible.
\end{abstract}

\section{Introduction}

The world's population in 2020 reached 7.8 billion people, while in 2019 , it was 7.7 billion people. Based on these data, the development of the world's population in 2020 is approximately 8.1 million people. One of these numbers is Indonesia's population of 269.6 million people. The results of the 2018 basic health research conducted by the Health Research and Development Agency show that $8 \%$ of the Indonesian population still faces the problem of malnutrition, which can reduce people's quality of life and productivity.

In order to anticipate the problems mentioned above, Indonesia imports fish meal and fish oil every year for approximately 200 million US dollars. The importing of fish meal and fish oil is intended to develop sustainable fish farming. Therefore, in terms of food security strategies, aquaculture and fish are sources of food energy that can be accessed by major lowincome households [2].

Nowadays, in Indonesia, the problem of fish feed supply has long been felt by fish cultivators until now. Although the supply is smooth, the price of fish feed in the market is still high because the raw materials for making feed are still imported. To overcome this, the

*Corresponding author: harjasupena@gmail.com 
Government continues to look for a formula to produce quality fish feed at an affordable price. One of them is maggot cultivation.

Maggot is an organism derived from the Black Soldier Fly (BSF) egg which undergoes metamorphosis in the second phase after the egg phase and before the pupa phase, then turns into an adult fly. Maggot undergoes 5 (five) stages in its life cycle. The five stadia are the adult phase, egg phase, larva phase, prepupa phase, and pupa phase [1]. Figure 1 is the life cycle of maggots.

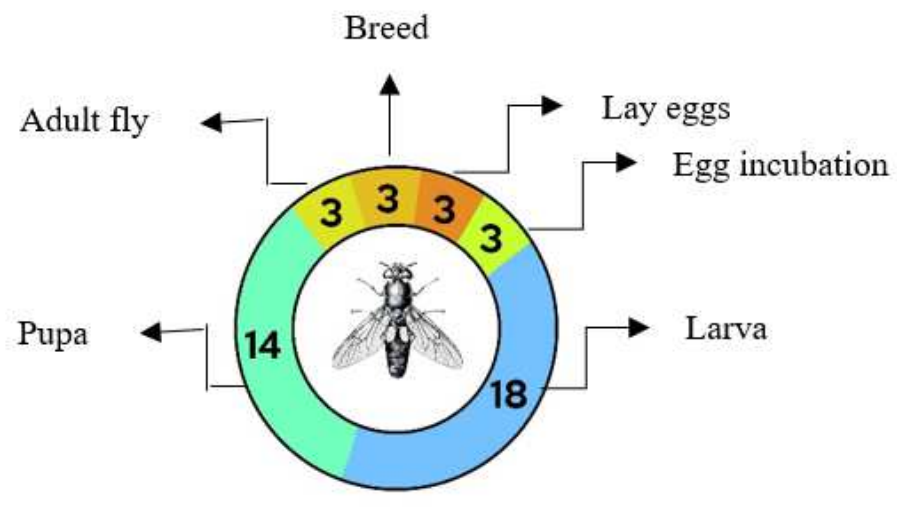

Fig. 1. Maggot life cycle [1]

Although other raw materials can also be used as alternative raw materials, the Government seems to focus on maggot because there are many benefits and advantages that other raw materials do not have. These advantages are because maggot contains high and quality protein needed by fish, which contains $45 \%$ protein in the feed formulation. Besides that, the manufacture is easy to do with low and affordable production costs because the main media is organic waste. To achieve this, the right facilities and infrastructure are needed. Considering these two things are the core factors of various production factors [7].

In addition, the success of the maggot cultivation business is also highly dependent on expertise in the fields of marketing, production, finance, and human resources [13]. Another benefit of maggot is the processing of organic waste, which is usually produced by households. By being processed into a maggot, the garbage will disappear, and at the same time, it will become food for fish. Maggot has a large enough opportunity to be used as an alternative raw material for high protein feed (fish) for fish growth [4].

Fish that consume maggots will have good growth, so it is expected that consumers who consume the fish will have their satisfaction level fulfilled [9]. One of the regions in Indonesia that contributes to the production of maggots is Bogor City, West Java. The purpose of the study was to determine the income and feasibility of maggot cultivation in Bogor city.

\section{Materials and methods}

\subsection{Research location and time}

The research was conducted at the Maggot cultivation business in Bogor, namely the Reduce Reuse Recycle Waste Disposal Site (TPS 3R) of the Environmental Service (DLH). The location of this research was determined purposively considering that Bogor was chosen as a pilot project in the scope of West Java and Nationally in the field of fisheries. The research was conducted for three months, namely July - September 2020. 
Sampling used the purposive sampling method, which means it was done intentionally at 6 TPS 3R from 27 TPS 3R spread over six sub-districts in Bogor City. The selection and determination of the $63 \mathrm{R}$ TPS are because the $63 \mathrm{R}$ TPS are already more active and productive in their maggot cultivation business activities than the other $213 \mathrm{R}$ TPS. The primary and secondary data obtained through interviews and literature, and the internet were then processed and analyzed using quantitative and qualitative descriptive approaches using income and feasibility analysis [3] as follows:

\subsection{Income analysis}

Followed by Kardyo and Wellem (2012) Formula of profit received by the owner are as follows:

$$
\operatorname{Pd}(\text { п) }=\mathrm{TR}-\mathrm{TC}
$$

$\operatorname{Pd}(\pi)=$ Total income received by Cultivators, $\mathrm{TR}=$ Total revenue received by the Cultivator $\mathrm{TC}=$ Total cost (cost) incurred by the Cultivator

\subsection{Business feasibility analysis}

\subsubsection{Revenue Cost Ratio (R/C Ratio)}

$$
R / C \text { Ratio }=\frac{T R}{T C}
$$

$\mathrm{R} / \mathrm{C}=$ Return over Cost; $\mathrm{TR}=$ Total Revenue, $\mathrm{TC}=$ Total Cost. The decision criterias for $\mathrm{R} / \mathrm{C}$ is follow: 1) $\mathrm{R} / \mathrm{C}>1$ (feasible). 2) $\mathrm{R} / \mathrm{C}<1$ (not feasible), and $\mathrm{R} / \mathrm{C}=1=$ Break Even

\subsubsection{Break-Even Point (BEP)}

$\mathrm{BEP}$ of price $\left(\mathrm{BEP}_{\mathrm{Rp}}\right)$ follows the formula below:

$\mathrm{BEP}$ of unit $\left(\mathrm{BEP}_{\text {unit }}\right)$ follows the formula below:

$$
B E P(R p)=\frac{F C}{1-\frac{V C}{S}}
$$

$$
B E P(\text { unit })=\frac{F C}{p-b}
$$

Where FC $=$ Fixed Cost, $\mathrm{VC}=$ Variable Cost, $\mathrm{S}=$ Sales, $\mathrm{p}=$ Selling Price, $\mathrm{b}=$ Variable Cost Per Unit

\section{Results}

\subsection{Bogor city location}

Bogor City is located at an altitude of $190-330 \mathrm{~m}$ above sea level. The area of the city of Bogor is 11,850 hectares and consists of 6 namely: West Bogor, South Bogor, Central Bogor, East Bogor, North Bogor, and Tanah Sareal 


\subsection{Maggot cultivator data}

Based on the Bogor City Environmental Service (DLH) survey data in 2019, 27 Reduce Reuse Recycle (TPS 3R) waste disposal sites spread across six sub-districts in Bogor City. Of the 27 3R polling stations in Bogor City, six 3R polling stations have been selected as research data samples and represent every sub-district in Bogor City[3]. The following 6 TPS $3 \mathrm{R}$ representing six sub-districts complete with the names of the managers, can be seen in Table 1.

Table 1. Location and name of TPS 3R manager in Bogor City as research sample

\begin{tabular}{|c|c|c|c|}
\hline No. & Districts & Name of TPS 3R & Manager Name \\
\hline 1 & West Bogor & Rusunawa & Mr. Mumuh \\
2 & South Bogor & Kertamaya & Mr. Rachmat \\
3 & Centre Bogor & Paledang & Mr. Hadi \\
4 & East Bogor & Mutiara Bogor Raya & Mrs. Ani Hayu S. \\
5 & North Bogor & Ciparigi & Mr. H.Sabur \\
6 & Tanah Sareal & Kayu Manis 2 & Mr. Bento \\
\hline
\end{tabular}

Source: Processed Data, 2020

\subsection{Maggot cultivation business}

Table 2. Types and total value of maggot production at 6 TPS 3R Bogor City

\begin{tabular}{|c|c|c|c|}
\hline No. & Maggot Production Type & $\begin{array}{c}\text { Production Quantity } \\
(\mathrm{Kg})\end{array}$ & Production Value (Rp.000) \\
\hline 1 & Maggot Eggs & 0.5 & 3,190 \\
2 & Fresh Maggot & 3,360 & 17,040 \\
3 & Fertilizer/ Kasgot & 2,635 & 6,265 \\
4 & Non-Organic Waste & 15,000 & 15,000 \\
\hline & Amount & $10,995.5$ & 41,495 \\
\hline
\end{tabular}

Source: Processed Data, 2020

\subsection{Maggot cultivation business analysis}

Table 3. List of maggot cultivation business recapitulation at 6 TPS 3R Bogor City

\begin{tabular}{|c|c|c|}
\hline No. & Business Analysis Parameters & Total Value (Rp.000) \\
\hline 1 & Investment & 60,187 \\
2 & Depreciation & $1,431.53$ \\
3 & Fixed cost & $35,165.76$ \\
4 & Variable cost & 3,341 \\
\hline
\end{tabular}

Source: Processed Data, 2020

The table above shows the maggot cultivation costs include fixed and variable costs from 6 3R TPS. Fixed costs consist of labor and depreciation. The variable costs consist of egg seeds, burlap sacks, packaging, and containers (jars). In contrast, the return or payback period is obtained from the total investment divided by operating profit multiplied by the production cycle. The investment consists of bio ponds, maintenance cages, filters, burlap sacks, packaging, and basins from a total of $63 \mathrm{R}$ TPS. 
Table 4. Results of feasibility analysis of maggot cultivation business at 6 TPS 3R Bogor City

\begin{tabular}{|c|l|c|c|}
\hline No. & Business Feasibility Indicator & Unit & Indicator Value \\
\hline 1 & Total Revenue & $(\mathrm{Rp} .000)$ & 41.495 \\
2 & R/C Ratio & $(\mathrm{Rp} .000)$ & 1.077 \\
3 & BEP $_{(\mathrm{Rp})}$ & $(\mathrm{Rp} .000)$ & $38,223.65$ \\
4 & BEP $_{\text {(Unit) }}$ & $\mathrm{Kg}$ & 8,112 \\
\hline
\end{tabular}

Source: Processed Data, 2020

\section{Discussions}

Based on the data in table 3 (Investment, depression, Fixed cost, and variable cost), then after being processed using the formula in the method subsection, the indicator values are obtained as shown in Table 4. Table 4 shows that the result of the R/C Ratio is 1.077 (1.1) that is obtained from a comparison between revenues and expenses [3]. The value means the business cultivation of maggots in Bogor City can be feasible [5] because the result of 1.1 means more than 1. According to [8], if the $\mathrm{R} / \mathrm{C}$ ratio is more than 1 , the business being carried is feasible or can be forwarded. It is feasible because the $\mathrm{R} / \mathrm{C}$ ratio of more than 1 means that the revenue is greater than the total cost [10]. Their research entitled Business Analysis of Maggot Cultivation as a Catfish Feed Alternative also stated that to raise 400 catfish seeds measuring 3-5 cm, as much as $250 \mathrm{~kg}$ (30 sacks) of pelleted feed are needed. Meanwhile, with $100 \mathrm{~kg}$ of culture media, raw materials obtained as many as $60-70 \mathrm{~kg}$ of maggot larvae.

According to [11] that $100 \mathrm{~kg}$ of raw material for culture media can produce larvae as much as ' $60-70 \mathrm{~kg}$ where the larvae are produced within two weeks and are in the second instar larval stage, which grows about $10 \mathrm{~mm}$ until it reaches the third instar larvae stage of 15-20 mm. Therefore, when compared between pellet feed and maggot, the pellet feed is much more, reaching eight bags while maggot only reaches 3.5 or 4 bags. Thus, $50 \%$ of catfish farming businesses have been able to save $22.74 \%$ of feed costs. With this amount of feed savings, in terms of quality and quantity based on research, it is stated that maggot has the potential as a substitute feed for catfish [12]. If the whole feeding uses $100 \%$ maggot, this is very profitable because it can save costs by $45.48 \%$.

$\mathrm{BEP}_{(\mathrm{Rp})}$ showed the result of Rp. 38,223,654,- and $\mathrm{BEP}_{(\text {(nit) }}$ showed a yield of $8,112 \mathrm{~kg}$. According to Mahyuddin (2008), $\mathrm{BEP}_{(\mathrm{RP})}=\mathrm{Rp} .38,223$ is smaller than the total production value, while the $\mathrm{BEP}_{\text {(nit) }}$ is $8,112 \mathrm{~kg}$ less than the total production. Based on these results, the maggot cultivation business in Bogor can is said to be Feasible[6] /continued because it is still at a good level. The Break-Even Point (BEP) maggot cultivation business is at $\mathrm{EP}_{(\mathrm{Rp})}=$ Rp. 41,495,000,- and $\mathrm{BEP}_{\text {(unit) }}=8,945 \mathrm{~kg}$.

\section{Conclusion}

The income/revenue of the maggot cultivation business in Bogor City is Rp. 41,495,000. The maggot cultivation business in the city of Bogor can be said to be feasible/continued because it is still at a profitable level. Where is the Break-Even Point (BEP) maggot cultivation business is at $\mathrm{BEP}_{(\mathrm{Rp}))}=\mathrm{Rp} .41,495,000,-$ and $\mathrm{BEP}_{(\text {unit })}=8,945 \mathrm{~kg}$. 


\section{References}

1. S. Elvita, Determination of Optimal Feeding Rate of Black Soldier Fly (Hermetia illucens) Larvae in Reducing Market Organic Waste (10 November Institute of Technology, Surabaya, 2015)

2. M. Firdaus, 2011. Manajemen Agribisnis (Bumi Aksara, Jakarta, 2011)

3. K.P. Kardyo, M. Wellem, Aquaculture Operations Production Management (Bogor, 2012)

4. Koentjoroningrat, Community Research Methods (Gramedia Pustaka Utama, Jakarta, 1993)

5. P. Kotler, G. Amstrong. Marketing Fundamentals (Intermedia, Jakarta, 1992)

6. P. Kotler, Marketing Management. Analysis, Planning and Control - Vol. 1 (PT. Prenhallindo, Jakarta, 1995)

7. F. Laksana, Marketing Management: Practical Approach (Graha Ilmu, Yogyakarta, 2008)

8. K. Mahyuddin, Complete Guide to Catfish Agribusiness (Penebar Swadaya, Jakarta,2008)

9. M. Primyastanto, Fisheries Business Feasibility Study (UB Press, Malang, 2011)

10. R.U.A. Fauzi, E.R.N. Sari, Industria 7, 1 (2018)

11. Hanim, et al., Maggot BSF Cultivation Development Strategy As Economic Resilience

12. During Pandemic Scientific J. Management Sci. 112 (2021)

13. Y. Harahap, The Maggot: As a Sustainable Solution of Organic Waste Management and Animal Feeding Needs, OISAA Journal of Indonesia Emas 2, 77-80 (2019)

14. Rahardi, Fishery Agribusiness (Penebar Swadaya. Jakarta, 2008) 